\title{
The First Record of Successful Breeding of the Male Saker Falcon at the Age of One Year in the Altai-Sayan Region, Russia
}

\section{ПЕРВЫЙ СЛУЧАЙ УСПЕШНОГО РАЗМНОЖЕНИЯ САМЦА БАЛОБАНА В ВОЗРАСТЕ ОДНОГО ГОДА В АЛТАЕ-САЯНСКОМ РЕГИОНЕ, РОССИЯ}

\author{
Nikolenko E.G., Karyakin I.V., Shnayder E.P. (Sibecocenter LLC, Novosibirsk, Russia) \\ Kuksin A.N. (State Nature Biosphere Reserve "Ubsunurskaya kotlovina", Kyzyl, Republic \\ of Tyva, Russia) \\ Николенко Э.Г., Карякин И.В., Шнайдер Е.П. (ООО «Сибэкоцентр», Новосибирск, \\ Россия), \\ Куксин А.Н. (ФГБУ Государственный природный биосферный заповедник \\ «Убсунурская котловина», Кызыл, Республика Тыва, Россия)
}

\section{Контакт:}

Эльвира Николенко ООО “Сибэкоцентр" 630090, Россия, Новосибирск, а/я 547 тел: + 79231501279 elvira_nikolenko@mail.ru

Игорь Карякин ООО “Сибэкоцентр" 630090, Россия, Новосибирск, а/я 547 тел.: +79231543295 ikar_research@mail.ru

Елена Шнайдер ООО «Сибэкоцентр" 630090, Россия, Новосибирск, а/я 547 тел.: +79137956549 equ001@gmail.com

Александр Куксин ФГБУ Государственный природный биоссерный заповеАник "Убсу нурская котловина" 667010, Россия Республика Тыва, Кызыи, ул. Шагонарская, 64 artovec@yandex.ru

DOI: $10.19074 / 1814-8654-2018-37-256-258$

Способность к успешному размножению представителей Hierofalco в первый год жизни (на следуюшее лето после вылета из гнезАа) издавна известна (Аементьев, 1951a; $\Delta$ ементьев, 1951b), однако в основном все подобные случаи относятся к самкам. Самцы редко могут оставить потомство в первый гоА жизни. Это поАтверждено многочисленными наблюдениями, в том числе и в Алтае-Саянском экорегионе (АСЭР), на примере балобана (Falco cherrug). Так, например, за послелнее десятилетие в АСЭР отмечена смена старых самок на молодых более чем в 100 парах, причём почти в половине случаев размножение у этих самок прошло успешно, а в 21 паре произошла смена самцов (см. Карякин, Николенко, 2008; 2011; Карякин и Ар., 2014, 2018 на стр. 71-141). Но успешное размножение при смене в паре самца на годовалую птицу отмечено только в одном случае - в Республике Тыва в 2018 г. Об этом случае и пойдёт речь в Аанном сообшении.

В ходе обследования территории бывших сельхозугодий, не используюшихся по назначению более 30 мет, 9 мая 2018 г. на одиночно растушем карагаче (Ulmus pumila), в старой постройке мохноногого курганника (Buteo hemilasius) была обнаружена самка балобана на киацке из 4-х яиц. Сроки её размножения запаздывами на 20 Аней, относительно соседних пар балобанов. И это не удивительно, так как рялом с гнезАом были найдены останки старого самца, погибшего по каким-то
The ability of Hierofalco species to breed successfully in the age of 1 year (second summer) has long been known for females (Dementiev, 1951a; Dementiev, 1951b). For a male, it is very unlikely to bring offspring during the $1 \mathrm{CY}$, which is confirmed by numerous observations, including the example of the Saker Falcon (Falco cherrug) in Altai-Sayan Ecoregion (ASER). Over the past ten years in ASER, we witnessed a replacement of mature females by the young ones in more than 100 pairs and in about half of all cases $1 \mathrm{CY}$ females bred successfully. At the same time, a male replacement by $1 \mathrm{CY}$ falcons was also noted in 21 pairs (see Karyakin, Nikolenko, 2008; 2011; Karyakin et al., 2014, 2018 on pages 71-141). However, in the case of male replacement, no successful breeding was observed except only one case in the Tyva Republic in 2018, which is the subject of the present report.

On May 9 of 2018, we examined the territory of former agricultural lands abandoned for more than 30 years. During the survey, we noted a Saker Falcon female on the clutch of four eggs. Her nest was made in the old nest of the Upland Buzzard (Buteo hemilasius) built on a solitary elm tree (Ulmus pumila). The breeding terms of this bird were 20 days late, compared to neighboring pairs of Sakers. The shift in breeding term was probably related to the death of a male partner whose remains we found near the nest. The corps was at least 2.5-3-month-old. It was a mature male and the cause of his death remains unknown, 


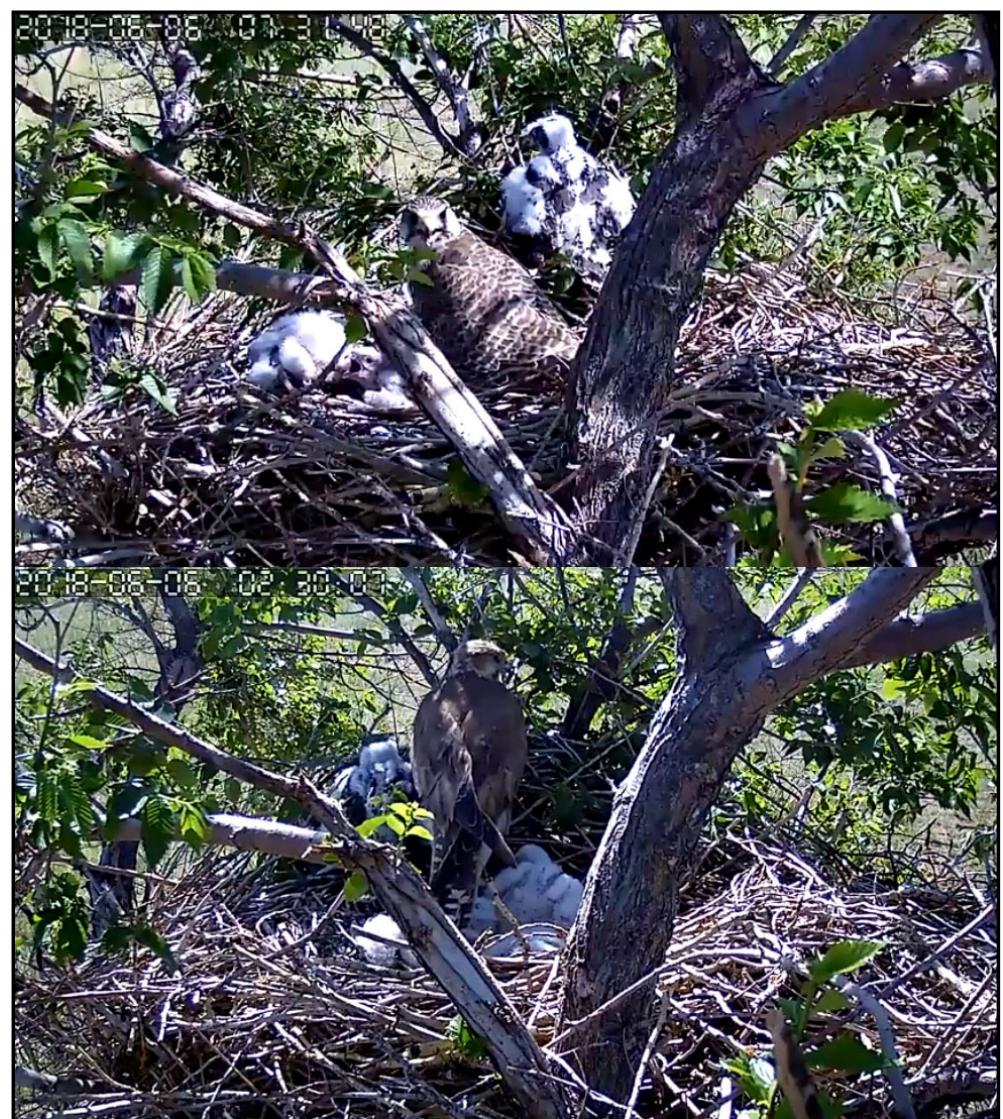

Contact:

Elvira Nikolenko

LLC Sibecocenter

P.O. Box 547,

Novosibirsk,

Russia, 630090

tel.: +79231501279

elvira_nikolenko@mail.ru

Igor Karyakin

LLC Sibecocenter

P.O. Box 547

Novosibirsk,

Russia, 630090

tel.: +79231543295

ikar_research@mail.ru

Elena Shnayder

LLC Sibecocenter

P.O. Box 547,

Novosibirsk,

Russia, 630090

tel.: +79137956549

equ001@gmail.com

Aleksandr Kuksin State Nature Biosphere Reserve "Ubsunurskaya kotlovina" Republic of Tyva, Russia

Shagonarskaya str., 64, Kyzyl, Republic of Tyva, Russia, 667010 artovec@yandex.ru причинам не менее 2,5-3 месяцев назал (возможно, он был убит более крупным пернатым хишником). Новый самец в паре оказался птицей в возрасте 1 года, ешё не сменившей свой ювенильный наряд на взрослый (рис. 1).

ияя контроля за успехом размножения пары, 6 июня на гнездо была установлена веб-камера. Птенцам в гнезде в это время было 10-15 дней. В ходе анализа полученного видеоряда было выяснено, что основная роль по Аобыче пропитания лежит на самке. На кажыые 4 приноса добычи самки приходится 1 принос Аобычи самцом, который большую часть времени проводит на гнезде. В результате было принято решение подкармливать выводок раз в 2 дня $\Delta$ о начала оперения птенцов, подбрасывая в гнезАо тушки мышей и хомяков. Несмотря на такое поведение самца, благодаря Аополнительной подкормке и активности самки, пара успешно выкормила 4-х птенцов $А$ вылета.

В течение недели после вылета из гнезда один из слётков погиб во время июльского урагана с грахом (вероятно от переохиажмения и голода). Визуальные наблюдения за парой показаии, что в течение месяца после вылета птенцов из гнезда основная роль в Аокармливании выводка продолжама оставаться на самке. probably he was killed by a larger raptor. A new male in this pair turned out to be a $1 \mathrm{CY}$ bird still in juvenile plumage (fig. 1).

To get more data from this pair, a web-camera was installed on the nest on June 6 . At that time nestlings were 10-15 days old. The analysis of a footage revealed that in this pair the female plays the main role in food provision. For each case of prey provisioning by the male, there were 4 made by the female. Male actually spent most of the time in the nest. To help the female we begun to add some extra prey (sacrificed mice and hamsters) to the nest every second day until the end of nestling period. As a result, the pair successfully fed all 4 juveniles, despite male's inexperience.

Рис. 1. Самка (вверху) и самец (внизу) балобана (Falco cherrug) на гнезде с птенцами. Самка старше 2-х лет, самец в возрасте одного года. Фото с вебкамеры.

Fig. 1. The female (above) and the male (below) Saker Falcon (Falco cherrug) at the nest with nestlings. The female is over the age of two, the male is one year old. Photo from the web-camera.

\section{Митература}

Аементьев Г.П. Отряд хишные птицы: Ассіріtres или Falconiformes. - Птицы Советского Сoюза. Т. 1. М.: Сов. Наука, 1951 а. С. 70-341. [Dementiev G.P. Birds of prey: Accipitres or Falconiformes. - Birds of the Soviet Union. Vol. 1. Moscow, 1951 a: 70-341. (in Russian).] URL: http://rrrcn.ru/ru/archives/14389 $\triangle$ ата обрашения: 20.12.2018.

$\triangle$ ементьев Г.П. Сокола-кречеты. Систематика, распространение, образ жизни и практическое значение. - Материамы к познанию фауны и флоры СССР МОИП. ОтА. зоол. Вып. 29 (XLIV). M., 1951 b. 188 c. [Dementiev G.P. Gyrfalcons. Systematics, distribution, ecology and practical importance. - Data to the knowledge of the fauna and flora of the USSR. Moscow Society of Naturalists. Dep. Zool. No. 29 (XLIV). Moscow, 1951 b: 1-188. (in Russian).] URL: http://rrrcn.ru/ru/archives/11187 $\triangle$ ата обрашения: 20.12.2018.

Карякин И.В., Николенко Э.Г. Результаты мониторинга попумяции бамобана в Алтае-Саянском регионе в 2008 г., Россия. - Пернатые хишники и их охрана. 2008. № 14. С. 63-84. [Karyakin I.V., Nikolenko E.G. Monitoring Results on the Saker Falcon Population in the Altai-Sayan Region in 2008, Russia. - Raptors Conservation. 2008. 14: 63-84.] URL: http:// rrrcn.ru/ru/archives/25539 Аата обрашения: 20.12.2018.

Карякин И.В., Николенко Э.Г. Результаты проекта по восстановлению мест гнездования хишных птиц в Республике Тыва, Россия. - Пернатые хишники и их охрана. 2011. № 21. 
C. 14-83. [Karyakin I.V., Nikolenko E.G. Results of the Project for Restoration of Nesting Places of the Birds of Prey in the Republic of Tyva, Russia. - Raptors Conservation. 2011. 21: 14-83.] URL: http://rrrcn.ru/ru/archives/14336 Аата обрашения: 20.12.2018.

Карякин И.В., Николенко Э.Г., Шнайдер Е.П. Результаты мониторинга популяции балобана в Алтае-Саянском регионе в 2014 году, Россия. - Пернатые хишники и их охрана. 2014. № 29. C. 58-76. [Karyakin I.V., Nikolenko E.G., Shnayder E.P. Results of Monitoring of the Saker Falcon Population in the Altai-Sayan Region in
2014, Russia. - Raptors Conservation. 2014. 29: 58-76.] DOI: 10.19074/1814-8654-2014-29 58-76 URL: http://rrrcn.ru/ru/archives/25729 Аата обрашения: 20.12.2018.

Карякин И.В., Николенко Э.Г., Шнайдер Е.П. Бамобан в Аитае-Саянском регионе: результаты мониторинга в 2016-2018 гг. - Пернатые хишники и их охрана. 2018. № 37. С. 95-165. [Karyakin I.V., Nikolenko E.G., Shnayder E.P. Saker Falcon in the Altai-Sayan Region: Results of Monitoring in 2016-2018. - Raptors Conservation. 2018. 37: 95-165.] DOI: 10.19074/18148654-2018-37-95-165.

\section{Подписка на журнам на 2019 г.: Subscription on the Journal in 2019:}

\begin{tabular}{|c|c|c|c|c|}
\hline & \multicolumn{2}{|c|}{$\begin{array}{l}\Delta \wedge я \text { членов RRRCN* } \\
\text { For RRRCN members* }\end{array}$} & \multicolumn{2}{|c|}{$\begin{array}{l}\text { Ая всех остальных подписчиков } \\
\text { For other subscribers }\end{array}$} \\
\hline & $\begin{array}{c}\text { Чёрно-белый с } \\
\text { цветной обложкой } \\
\text { Black-and-white ver- } \\
\text { sion with a color cover } \\
\text { руб. / USD }\end{array}$ & $\begin{array}{l}\text { Полноцвет } \\
\text { Full color } \\
\text { version } \\
\text { руб. / USD }\end{array}$ & $\begin{array}{c}\text { Чёрно-белый с } \\
\text { цветной обложкой } \\
\text { Black-and-white ver- } \\
\text { sion with a color cover } \\
\text { руб. / USD }\end{array}$ & $\begin{array}{l}\text { Полноцвет } \\
\text { Full color } \\
\text { version } \\
\text { руб. / USD }\end{array}$ \\
\hline 1 экз. / 1 hard copy & $140 / 2.0$ & $950 / 13.5$ & $250 / 4.0$ & $1500 / 25.0$ \\
\hline 2 экз. / 2 hard copies & $260 / 4.0$ & 1800 / 26 & 480 / 7.0 & $2900 / 45.0$ \\
\hline 3 экз. / 2 hard copies & $375 / 5.5$ & $2550 / 36.5$ & $690 / 10.5$ & $4200 / 63.0$ \\
\hline 4 экз. / 2 hard copies ** & $480 / 7.0$ & $3200 / 46.0$ & $880 / 13.0$ & $5400 / 80.0$ \\
\hline
\end{tabular}

* - о членстве в Российской сети изучения и охраны пернатых хишников можно узнать на сайте: http://rrrcn.ru/ru/about_the_network / More about a membership in the Russian Raptor Research and Conservation Network read on the web-site: http://rrrcn.ru/en/about_the_network

** - по цене за 4 экземпляра, можно заказать либо 4 печатных копии одного номера, либо по одной печатной копии 4-х номеров / for a price of 4 hard copies you can order 4 hard copies of one issue, or one hard copy of the 4 issues.

Аоставка по России оплачивается дополнительно по себестоимости почтовых расходов.

Оплатить заказ можно через систему Яндекс-деньги на сайте Российской сети изучения и охраны пернатых хишников http://rrrcn.ru/ru/for_sponsors мибо на счёт ООО «Сибэкоцентр».
Delivery expenses are be paid additionally according to prime cost of postage.

Please contact the editors to learn about the details of the payment (the contacts are available on p. 2)

Банковские реквизиты дяя перевода в рублях:

Получатель: ООО “Сибирский экологический центр"

ИНН 5445028176 КПП 544501001 ОГРН 1185476087015

Расчетный счет: № 40702810523120001411

в банке: Филиал "Новосибирский" ОАО "АИЬФА-БАНК", г. Новосибирск

БИК 045004774

Корр. счет № 30101810600000000774 в СИБИРСКОЕ ГУ БАНКА РОССИИ

Назначение платежа: подписка на журнаи "Пернатые хищники и их охрана"

Обязательно указывайте точное назначение платежа, как это смелано в образце!

Пожалуйста сообщайте нам о переводе денег (контактные Аанные доступны на стр. 2) 